\title{
Digestion and energy value of macerated sudangrass hay used in growing-finishing diets for feedlot cattle
}

\author{
Alejandro Plascencia Jorquera ${ }^{1}$, José Gerardo Serrano Ponce ${ }^{1}$, Berenice Sánchez-Mendoza ${ }^{1}$, \\ Alberto Barreras Serrano ${ }^{1}$, José Fernando Calderón-Cortés ${ }^{1}$, María Alejandra López-Soto ${ }^{1}$, Martín \\ Francisco Montaño Gómez ${ }^{1}$, Richard Avery Zinn² \\ ${ }^{1} U A B C /$ Inst. de Investigaciones en Ciencias Veterinarias -21386 - Mexicali, Baja California - México. \\ ${ }^{2} U C$ Davis/Dept. of Animal Science - 95616 - Davis - USA. \\ *Corresponding author <alejandro.plascencia@uabc.edu.mx> \\ Edited by: Gerson Barreto Mourão
}

\begin{abstract}
Mechanical maceration enhances site and extent of digestion of low-moisture, low-quality forages. Four Holstein steers $(172 \pm 8 \mathrm{~kg})$ with cannulas in rumen and proximal duodenum were used in $4 \times 4$ Latin square design to evaluate the process of mechanical maceration of sudangrass hay on the characteristics of ruminal and total tract digestion. Treatments consisted of a steam-flaked corn-based growing diet supplemented with $21 \%$ forage (DM basis) as: i) wheat straw (Triticum aestivum, STRW), ii) sudangrass hay (Sorghum sudanense, SG), iii) macerated SG at intensity of 4,134 kPa (MAC600) and 4) macerated SG at intensity of 6,200 kPa (MAC900). All forages were ground to pass through a $3.8 \mathrm{~cm}$ screen before incorporation into complete mixed diets (21:79 forage to concentrate ratio). Maceration did not affect $(p \geq 0.17)$ on site and extent of OM, N and ADF, and DE of sudangrass supplemented diets. Characteristics of ruminal digestion of OM, ADF, starch, as well as, microbial efficiency (microbial $\mathrm{N}, \mathrm{g} \mathrm{kg}^{-1}$ of $\mathrm{OM}$ fermentad) and protein efficiency (nonammonia $\mathrm{N}, \mathrm{g} \mathrm{g}^{-1}$ of $\mathrm{N}$ intake) were not different $(p \geq 0.11)$ for wheat straw versus sudangrass supplemented diets. However, total tract digestion of $\mathrm{OM}, \mathrm{ADF}, \mathrm{N}$, and DE diet were greater $(p \leq 0.05)$ for sudangrass than for wheat straw supplemented diets. Using the replacement technique, DE value of SG averaged $9.59 \mathrm{MJ} \mathrm{kg}^{-1}$, very close to the expected value given its chemical composition. Mechanical maceration did not enhance the feeding value of sudangrass hay. Increase the intensity of maceration from 4,134 to $6,200 \mathrm{kPa}$ did not altered ruminal or total tract digestion of OM, NDF or energy value of processed hay.

Key words: Sorghum sudanense, feed value, maceration, steers, forages
\end{abstract}

\section{Introduction}

Mechanical maceration was initially developed to enhance drying rate and reduce selective leaf loss of freshly cut alfalfa (Medicago sativa; Hong et al., 1988; Shinners et al., 1988; Broderick et al., 1999). However, maceration applications have also been developed to enhance site and extent of digestion of low-moisture, low-quality forages such rice (Oryza sativa) straw (Plascencia et al., 2007), and the improvements in digestion and in digestible energy due to maceration may be more pronounced when the level of inclusion of macerated straws in growing-finishing diets is moderated (Ware et al., 2005). The latter process consists of sets of opposing corrugated rolls maintained within set tolerances of each other using hydraulic pressure.

Opposing rolls turning at differential speeds, crush and stretch the fiber, but forage remains otherwise, intact. Indentation during maceration greatly alters the fiber structural integrity and density, promoting microbial attachment, digestion and fast passage rate of fiber in high-quality highmoisture forage (Hintz et al., 1999). Very little information is presently available regarding the efficacy of mechanical maceration on digestion of grasses. In a preliminary study with lambs (Petit et al., 1994), maceration increased in situ ruminal DM, fiber digestion and total tract digestible energy of freshly cut timothy grass (Phleum pretense). However, in a subsequent study (Petit et al., 1997) in situ digestion was not affected by maceration of timothy grass. In contrast, Chiquette et al. (1994) reported decreased digestibility of $\mathrm{OM}$, and NDF for macerated vs. conventional timothy hay when fed as the as the sole ingredient to mature beef steers. Maceration intensity may be a reason for these inconsistencies. In these sense, Agbossamey et al. (2000) reported that total tract digestion of DM and fiber decreased linearly $(p<$ $0.01)$ with the level of intensity of maceration of freshly cut alfalfa. In northwestern Mexico, typical growing-finishing diet containing from 15 to $25 \%$ of forage and sudangrass hay is a primary source of forage used.

This experiment aimed at evaluating the effects of mechanical maceration of sudangrass hay on comparative site and extent of nutrient digestion in cannulated Holstein steers fed a growing-finishing diet containing $21 \%$ of forage.

\section{Materials and Methods}

The trial was conducted in northwestern Mexico $\left(32^{\circ} 40^{\prime} 7\right.$ " N; $115^{\circ} 28^{\prime} 6^{\prime \prime} \mathrm{W}$, about $10 \mathrm{~m}$ a.s.l, and under Sonoran desert conditions (BWh classification according Köppen). All procedures involving live animals were conducted within the guidelines of approved local official techniques of animal care.

Four Holstein steers $(172 \pm 8 \mathrm{~kg})$ with ruminal $(80 \mathrm{~mm}$ diameter) and duodenal cannulas (Zinn and Plascencia, 1993) 
were used in a $4 \times 4$ Latin square experiment design to evaluate the influence of maceration of sudangrass hay on the characteristics of ruminal and total tract digestion. Experimental diets were total mixed ration (TMR) and contained (DM basis) 64.0\% steam-flaked corn, $7.0 \%$ cane molasses, $3.7 \%$ fat, $1.4 \%$ urea, $1.4 \%$ limestone, $0.4 \%$ trace mineralized salt, $0.3 \%$ chromic oxide $\left(\mathrm{Cr}_{2} \mathrm{O}_{3}\right)$, and $21 \%$ forage as: i) wheat straw (STRW), ii) sudangrass hay (SG), iii) macerated SG, tension of the rollers was adjusted to provide pressure of 4,134 $\mathrm{kPa}$ (MAC600), and iv) macerated $\mathrm{SG}$, tension of the rollers was adjusted to provide pressure of $6,200 \mathrm{kPa}$ (MAC900). All forages were ground to pass through a $3.8-\mathrm{cm}$ screen before incorporation into complete mixed diets. $\mathrm{Cr}_{2} \mathrm{O}_{3}$ was used as an indigestible marker to estimate nutrient flows and digestibility. Chromic oxide was premixed with minor ingredients (urea, limestone and trace mineral salt) before incorporation into complete mixed diets to reach a final concentration of $0.3 \%$. The $\mathrm{Cr}_{2} \mathrm{O}_{3}$ concentration measured, according to the technique described by Hill and Anderson (1958), was $0.00289 \pm 6.75 \mathrm{E}-06 \mathrm{~g} \mathrm{~kg}^{-1}$ of diet DM in close agreement with the targeted $0.0030 \mathrm{~g} \mathrm{~kg}^{-1}$ diet, and therefore, daily intake of $\mathrm{Cr}_{2} \mathrm{O}_{3}$ averaged $11.04 \pm 0.47 \mathrm{~g}$ during experiment. All animals began to consume $\mathrm{Cr}_{2} \mathrm{O}_{3} 10$ days before starting the experiment.

Sudangrass (Sorghum sudanense) was harvested, from the second growth, field cured for 6 days, and baled using rectangular-bale baler equipment (New Holland, model 575). The bales were stored for 8 months before use in this study. Wheat straw (var. Rio Colorado C2003) was baled (New Holland, model 575) following grain harvest and stored for one month before its use in this study. In order to facilitate the tearing of the fiber, sudangrass hay was moistened by spraying with the addition of $10 \%$ water $(\mathrm{w} / \mathrm{v})$ before introduction into the macerator. The maceration processing (MAC) consisted of a single passage of moistened sudangrass hay throughout two corrugated rolls $(0.20 \times 0.68 \mathrm{~m})$ set at $0.0 \mathrm{~mm}$ clearance with differential speed of $8 \mathrm{rpm}\left(7 \times 10^{-3} \mathrm{~g}\right)$. Speed rolls were adjust to reach $20 \mathrm{rpm}\left(45 \times 10^{-3} \mathrm{~g}\right)$ and $28 \mathrm{rpm}\left(88 \times 10^{-3}\right.$ g). The roll pressures used were 4,134 $\mathrm{kPa}$ (MAC600) and $6,200 \mathrm{kPa}$ (MAC900). All forage treatments were ground in a hammer mill (Bear Cat \#1A-S, Westerns Land and Roller Co., Hastings, NE) with a $38-\mathrm{mm}$ screen before incorporation into complete mixed diets.

Steers were housed (indoors facilities) in individual pens (3.9 $\mathrm{m}^{2}$ ) with concrete floor covered by neoprene carpet, automatic waterers and individual feed bunk. All steers received straw treatment (Treatment 1) for ten days before initiation of the trial. Dry matter intake was restricted to $3.83 \mathrm{~kg}$ per day $(90 \%$ of ad libitum intake by steers at start of the experiment). Diets were fed in two equal proportions at $8 \mathrm{~h} 00$ and $20 \mathrm{~h} 00$ daily. Experimental periods consisted of a 10 day diet adjustment period followed by a 4 day collection period. During the collection period duodenal and fecal samples were taken from all steers, twice daily as follows: day 1, 7h50 and 13h50; day 2, 9h00 and 15h00; day 3, 10h50 and 16h50; and day 4, 12h00 and 18h00. Individual samples consisted of approximately $500 \mathrm{~mL}$ duodenal chyme and $200 \mathrm{~g}$ (wet basis) of fecal material. Samples from each steer and within each collection period were composited for analysis.
During the final day of each collection period, a ruminal sample was obtained from each steer $4 \mathrm{~h}$ after feeding via the ruminal cannula. Ruminal fluid was taken from ruminal ventral sac by vacuum pump (Cole Parmer Instrument, Vernon Hill, IL) using a tygon tube ( $3 / 4$ "; USP Lima, Ohio), and $\mathrm{pH}$ was determined (Orion 261S, Fisher Scientific, Pittsburgh, PA.) on fresh samples. Upon completion of the trial, ruminal fluid was obtained from all steers and composited for isolation of ruminal bacteria via differential centrifugation (Bergen et al., 1968). The microbial isolate served as the purine: $\mathrm{N}$ reference for estimation of microbial $\mathrm{N}$ contribution to chyme entering the small intestine (Zinn and Owens, 1986). Samples were subjected to all or part of the following analysis: DM (oven drying at $105{ }^{\circ} \mathrm{C}$ until no further weight loss; method 930.15, AOAC, 2000); ash (method 942.05, AOAC, 1986); Kjeldahl N (method 984.13, AOAC, 2000), ammonia N (method 941.04, AOAC, 2000); purines (Zinn and Owens, 1986); gross energy (GE; adiabatic calorimeter bomb, model 1271, Parr, Moline, IL), ADF (Goering and Van Soest, 1970), and starch (Zinn, 1990). Microbial organic matter (MOM) and $\mathrm{N}(\mathrm{MN})$ leaving the abomasum were calculated using purines as a microbial marker (Zinn and Owens, 1986). Organic matter fermented in the rumen (OMF) was considered equal to $\mathrm{OM}$ intake minus the difference between the amount of total OM reaching the duodenum and MOM reaching the duodenum. Feed $\mathrm{N}$ escape to the small intestine was considered equal to total $\mathrm{N}$ leaving the abomasum minus ammonia- $\mathrm{N}$ and $\mathrm{MN}$ and, thus, includes any endogenous contributions. The comparative digestible energy (DE, MJ kg-1) values for tested forages were estimated using the replacement technique (Plascencia and Zinn, 2002). It was assumed that the DE values of STRW are equal to the DE value of SG it replaced plus the change in the content in the complete diet brought about by the replacement. Given that the DE value of STRW is $7.54 \mathrm{MJ} \mathrm{kg}^{-1}$ (NRC, 1996), the DE values of sudangrass treatments were estimated as follow:

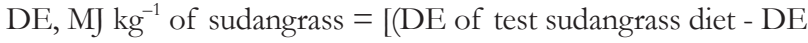
of straw diet) $/ 0.21]+7.54$. The constant 0.21 represents the amount of forage in the diet.

The trial was analyzed as a $4 \times 4$ Latin square design using the MIXED procedure (SAS Institute, 2009). Fixed effect consisted of treatment, and random effects consisted of steer and period. Treatment effects were tested for the following orthogonal components: i) STRW vs. SG; ii) SG vs. MAC, and ii) MAC600 vs. MAC900. Forage composition data was submitted to analysis of variance and F test, to investigate differences among forage fractions (N, ADF and ash). Variables with variances were submitted to Tukey test $(p<0.05)$ for mean comparisons. Contrasts were considered at $P$-value $\leq 0.05$, with a $P$-value of $\leq 0.10$ considered as a tendency approaching significance.

\section{Results and Discussion}

As expected (NRC, 1996; López-Soto et al., 2006), sudangrass contained $(p<0.01) 64.6 \%$ more $\mathrm{N}$ and $18.9 \%$ less ADF than straw (Table 1). The Maceration of sudangrass tended ( $p$ $=0.09)$ to increased fiber content $(4.1 \%)$ and increased $(p<$ $0.01)$ ash value. $\mathrm{N}$ content of sudangrass hay was not affected by maceration. Changes in composition of $\mathrm{N}$ and fibrous frac- 
tions have been observed following maceration of freshly cut legumes. This effect was presumably the result of leaf loss (Agbossamey et al., 2000), and loss of soluble cellular material during processing and handling of freshly cut forage (Lu et al, 1980). However, the tendency to increase on fiber and ash content in macerated hay is more apparent than real, and in agreement with Petit et al. (1994), these differences can be attributed to sampling procedures rather than the process of maceration. As a result of different chemical composition from SG treatments and STRW (Table 1), the average ADF intake was lower $(12.8 \%, p<0.01)$ and $\mathrm{N}$ intake was higher $(8.3 \%, p<0.01)$ for SG treatments (Table 2).

Table 1 - Physiochemical characteristic of forages tested ${ }^{\mathrm{A}}$.
Ruminal digestion of OM and starch were similar $(p \geq 0.11)$ between SG and STRW. Measures of ruminal ADF digestion, ruminal microbial efficiency and ruminal $\mathrm{N}$ efficiency were not different $(p \geq 0.27)$ for SG vs. STRW. Ruminal digestion of feed $\mathrm{N}$ was lower $(15.4 \%, p=0.03)$ for SG than for STRW. In a comparison of ground sudangrass hay $v$ s. ground wheat straw in growing-finishing diets containing $14 \%$ forage, Plascencia et al. (2007) did not detect differences $(p=0.08)$ in ruminal fiber and $\mathrm{N}$ digestion. Consistent with previous studies (Moore, 1990; Plascencia et al., 2007), total tract digestion of OM (2.7 $\%, p<0.01)$, ADF $(20.1 \%, p<0.01)$ and $\mathrm{N}(5.2 \%, p<0.01)$ were greater for SG than for STRW. Ruminal digestion of

\begin{tabular}{lcccc}
\hline & & \multicolumn{3}{c}{ Sudangras hay $^{\mathrm{B}}$} \\
\cline { 3 - 5 } Item & STRW $^{\mathrm{C}}$ & SG & MAC600 & MAC900 \\
\hline $\mathrm{DM}(\%)$ & $95.01 \pm 0.10$ & $94.74 \pm 0.14$ & $94.65 \pm 0.21$ & $94.95 \pm 0.20$ \\
$\mathrm{~N}(\%)$ & $0.40 \pm 0.03^{\mathrm{D}}$ & $1.13 \pm 0.02^{\mathrm{E}}$ & $1.12 \pm 0.03^{\mathrm{E}}$ & $1.13 \pm 0.02^{\mathrm{E}}$ \\
$\mathrm{ADF}(\%)$ & $52.09 \pm 0.82^{\mathrm{D}}$ & $42.25 \pm 0.98^{\mathrm{E}}$ & $43.35 \pm 1.96^{\mathrm{E}}$ & $44.76 \pm 2.24^{\mathrm{E}}$ \\
Ash $(\%)$ & $11.05 \pm 0.47^{\mathrm{D}}$ & $9.63 \pm 0.34^{\mathrm{E}}$ & $10.79 \pm 0.47^{\mathrm{D}}$ & $10.68 \pm 0.40^{\mathrm{D}}$ \\
\hline
\end{tabular}

${ }^{\mathrm{A}}$ Eight replicates $/$ forage. ${ }^{\mathrm{B}} \mathrm{SG}=$ sudangrass hay, MAC $600=$ macerated sudangrass intensity $4,134 \mathrm{kPa}, \mathrm{MAC} 900=$ macerated sudangrass intensity $6,200 \mathrm{kPa} .{ }^{\mathrm{C}} \mathrm{STRW}=$ wheat straw. ${ }^{\mathrm{D}, \mathrm{E}}$ Rows with different letters differ $(p<0.05)$.

Table 2 - Influence of maceration of sudangras hay on site and extent of digestion in cannulated Holstein steers $(173 \pm$ $7.8 \mathrm{~kg}$ ) fed a growing-finishing diet contained $21 \%$ of forage (Dry matter basis).

\begin{tabular}{|c|c|c|c|c|c|c|c|c|}
\hline \multirow[b]{2}{*}{ Item } & \multirow[b]{2}{*}{ STRW $^{\text {B }}$} & \multicolumn{4}{|c|}{ Sudangrass hay ${ }^{\mathrm{A}}$} & \multicolumn{3}{|c|}{$P$ value } \\
\hline & & SG & MAC600 & MAC900 & SEM & $\begin{array}{c}\text { STRW vs. } \\
\text { SG }\end{array}$ & SG vs. MAC & MAC600 vs. MAC900 \\
\hline \multicolumn{9}{|l|}{ Intake (g per day) } \\
\hline $\mathrm{DM}^{\mathrm{C}}$ & 3,835 & 3,832 & 3,835 & 3,832 & 13.7 & 0.62 & 0.77 & 0.62 \\
\hline $\mathrm{OM}^{\mathrm{D}}$ & 3,569 & 3,578 & 3,571 & 3,569 & 12.8 & 0.57 & 0.83 & 0.88 \\
\hline Starch & 1,447 & 1,447 & 1,447 & 1,446 & 1.1 & 0.99 & 0.99 & 0.92 \\
\hline $\mathrm{ADF}^{\mathrm{E}}$ & 543 & 463 & 473 & 484 & 4.1 & $<0.01$ & 0.48 & 0.44 \\
\hline $\mathrm{N}$ & 66 & 72 & 72 & 72 & 0.3 & $<0.01$ & 0.99 & 0.99 \\
\hline GE, MJ per day ${ }^{\mathrm{F}}$ & 65.23 & 65.65 & 65.61 & 65.40 & 0.77 & 0.13 & 0.95 & 0.27 \\
\hline \multicolumn{9}{|c|}{ Ruminal digestion ( $\%$ intake) } \\
\hline $\mathrm{OM}$ & 56.18 & 58.71 & 57.74 & 57.83 & 1.341 & 0.11 & 0.46 & 0.95 \\
\hline Starch & 79.68 & 77.59 & 77.66 & 78.96 & 1.961 & 0.39 & 0.72 & 0.59 \\
\hline $\mathrm{ADF}$ & 25.54 & 29.99 & 26.70 & 28.66 & 2.893 & 0.32 & 0.54 & 0.65 \\
\hline Feed N & 74.55 & 63.06 & 66.27 & 65.15 & 3.563 & 0.03 & 0.50 & 0.80 \\
\hline Microbial efficiency ${ }^{\mathrm{G}}$ & 23.3 & 24.3 & 24.6 & 24.8 & 0.69 & 0.31 & 0.72 & 0.83 \\
\hline N efficency ${ }^{\mathrm{H}}$ & 0.97 & 1.03 & 1.02 & 1.03 & 0.27 & 0.11 & 0.91 & 0.89 \\
\hline \multicolumn{9}{|c|}{ Total tract digestion $(\%)$} \\
\hline $\mathrm{OM}$ & 78.87 & 81.10 & 80.10 & 80.22 & 1.011 & $<0.01$ & 0.17 & 0.87 \\
\hline Starch & 97.51 & 98.26 & 97.82 & 97.70 & 1.51 & 0.18 & 0.26 & 0.75 \\
\hline $\mathrm{ADF}$ & 32.91 & 41.22 & 38.15 & 42.18 & 2.94 & 0.04 & 0.73 & 0.28 \\
\hline $\mathrm{N}$ & 73.08 & 77.08 & 77.80 & 76.76 & 1.353 & $<0.01$ & 0.23 & 0.63 \\
\hline DE diet, $\%$ & 78.04 & 80.57 & 79.89 & 79.96 & 0.945 & 0.02 & 0.38 & 0.93 \\
\hline DE diet, $\mathrm{MJ} \mathrm{kg}{ }^{-1}$ & 13.27 & 13.77 & 13.69 & 13.65 & 0.038 & $<0.01$ & 0.26 & 0.85 \\
\hline
\end{tabular}

${ }^{\mathrm{A}} \mathrm{SG}=$ sudangrass hay, MAC $600=$ macerated sudangrass intensity $4,134 \mathrm{kPa}$, MAC $900=$ macerated sudangrass intensity $6,200 \mathrm{kPa} .{ }^{\mathrm{B}}$ STRW $=$ wheat straw. ${ }^{\mathrm{C}}$ Dry matter. ${ }^{\mathrm{D}}$ Organic matter. ${ }^{\mathrm{E}}$ Acid detergent fiber. ${ }^{\mathrm{F}}$ Gross energy. ${ }^{\mathrm{G}}$ Microbial N, g $\mathrm{kg}^{-1} \mathrm{OM}$ fermented. ${ }^{\mathrm{H}}$ Nonammonia $\mathrm{N}$ entering the small intestine, $\mathrm{g} \mathrm{g}^{-1} \mathrm{~N}$ intake. ${ }^{\mathrm{I}}$ Digestible energy 
OM, ADF and starch were not different ( $p \geq 0.46$ ) for SG and MAC. To our knowledge, no comparable information about the impact of maceration on in vivo ruminal digestion of macerated grass hay is available in the literature. In a preliminary study (Petit et al., 1994), maceration increased in situ ruminal $\mathrm{DM}$ and fiber digestion of freshly cut timothy grass. However, in a subsequent study (Petit et al., 1997) in situ digestion was not affected by maceration of timothy grass.

Total tract digestibility of OM, ADF, $\mathrm{N}$ and starch were not different $(p \geq 0.17)$ for SG vs. MAC. Likewise, Petit et al. (1997) reported no effect of maceration on total tract $\mathrm{OM}$ and fiber digestion of timothy hay. In contrast, Hong et al. (1988) and Petit et al. (1994) reported greater total tract $\mathrm{OM}$ digestion for macerated vs. conventional timothy grass hay. Chiquette et al. (1994) reported decreased digestibility of OM, and NDF for macerated $v$. conventional timothy hay when fed as the as the sole ingredient to mature beef steers. The variation in results of macerated timothy hay on ruminal digestion of $\mathrm{OM}$ and NDF is not clear. In these studies, the maceration process was carried out with freshly cut forage and at different stages of maturity (early head stage, $10 \%$ of head stage or flowering stage), and therefore with different moisture content at time of processing. Furthermore, different drying processes were utilized after that forage was macerated (forced-air-dried or field dried). These conditions could be the main reason for variation in results observed between these studies. Another possibility is the level of forage inclusion. In studies conducted with macerated straw: inclusion at a level of $14 \%$ improved digestion (Plascencia et al., 2007); inclusion at $40 \%$, reduced it (Lopez-Soto et al., 2006); while in this study, inclusion at $15 \%$ of macerated straw did not show differences (Ware et al., 2005).

Intensity of the maceration process (MAC600 vs. MAC900) did not affect $(p \geq 0.28)$ measures of site and extent of digestion. Agbossamey et al. (2000) reported that total tract digestion of DM and fiber decreased linearly $(p<0.01)$ with the level of intensity (one, two or three passages through three knurled steel rolls) of maceration of freshly cut alfalfa under poor drying conditions (precipitation in first $48 \mathrm{~h}$ ). Increases in alfalfa content of $\mathrm{NDF}$ and ADF with more intensive mechanical conditioning may be explained partly by leaf shatter, partly by enhanced leaching under rainy conditions (Savoie et al. 1993) and partly by increased respiration during prolonged wilting (Kraus et al. 1998). These losses tend to be greater in the leaf and non-fibrous fractions (cell content), thereby resulting in higher final fiber content, and a lower digestion of DM. Contrary to the present study, the study conducted by Agbosammey et al. (2000) did not specified the pressure exerted between rollers and the "intensity" was means by the number of times that the freshly cut alfalfa was passed through the rollers.

Maceration did not affect $(p=0.38)$ DE value of sudangrass hay supplemented diets. Accordingly to the replacement technique, the DE values of sudangrass treatments averaged $9.59 \mathrm{MJ} \mathrm{kg}^{-1}\left(9.92,9.55\right.$ and $9.34 \mathrm{MJ} \mathrm{kg}^{-1}$, for SG, MAC600 and MAC9000, respectively). This value is 0.93 the tabular DE value (NRC, 1996), and 0.99 of expected DE value based on its $\mathrm{ADF}$ content of $\left[\mathrm{DE}, \mathrm{MJ} \mathrm{kg}{ }^{-1}=(((59.2+1.32 * \mathrm{ADF} \%)-\right.$ $\left.\left.\left(0.0338 \mathrm{ADF}^{\wedge} 2\right)\right) * 0.04409\right) * 4.1868$; Rohweder et al., 1978]. Petit et al. (1997) reported no effect of maceration of timothy hay on diet DE. In contrast, higher values of digestibility energy content of forage were reported by Hong et al. (1988) and Petit et al. (1994) for sheep fed macerated hay compared with conventional hay.

\section{Conclusions}

At the level of forage inclusion (21\%), the energy value of medium-quality hay (such sudangrass hay) did not enhanced by mechanical maceration. Increase the intensity of maceration from 4,134 to $6,200 \mathrm{kPa}$ did not altered ruminal or total tract digestion of OM, NDF or energy value of processed hay.

\section{Acknowledgements}

To Mr. Francisco Rivero, Ganadera EFRAL, Mexicali, México and the Secretaría de Fomento Agropecuario de $\mathrm{BC}$, which partially support the study through the grants "Fondo Alianza para el Campo". The macerator machine is a prototype and it was designed and built jointly by staff of Universidad Autónoma de Baja California and University of California, Davis.

\section{References}

Agbossamey, Y.R.; Savoie P.; Petit, H.V. 2000. Effect of intensity of maceration on digestibility and intake of alfalfa hay and silage fed to sheep. Canadian Journal of Animal Science 80:113-121.

Association of Official Analytical Chemists-International [AOAC]. 2000. Official Methods of Analysis. 17ed. AOAC, Gaithersburg, MD, USA.

Bergen, W.G.; Purcer, D.B.; Cline, J.H. 1968. Effect of ration on the nutritive quality of rumen microbial protein. Journal of Animal Science 27:14971501.

Broderick, G.A.; Koegel, R.G.; Mauris, M.J.C.; Schneeberger, E.; Krause, T.J. 1999. Effect of feeding macerated alfalfa silage on nutrient digestibility and milk yield in lactating dairy cows. Journal of Dairy Science 82:24722485.

Chiquette, J.; Savoie, P.; Lirette, A. 1994. Effects of maceration at mowing on digestibility and ruminal fermentation of timothy hay in steers. Canadian Journal of Animal Science 74: 235-242.

Goering, H. K.; Van Soest, P.J. 1970. Forage Fiber Analysis (Apparatus, Reagents, Procedures, and Some Applications). USDA/ARS, Washington, DC, USA. (Agriculture Handbook, 379).

Hill, F.N.; Anderson, D.L. 1958. Comparison of metabolizable energy and productive energy determination with growing chicks. Journal of Nutrition 64:587-594.

Hintz, R.W.; Koegel, R.G.; Krause, T.J.; Mertens, D.R. 1999. Mechanical maceration of alfalfa. Journal of Animal Science 77:187-193.

Hong, B.J.; Broderick, G.A.; Panciera, M.P.; Koegel, R.G.; Shinners, K.J. 1988. Effects of shredding alfalfa stems of fiber digestion determined by in vitro procedures and scanning electron microscopy. Journal of Dairy Science 71:1536-1545.

Lopez-Soto, M.A.; Arellano, G.E.; Barreras, A.; González, V.M.; García, D.M.; Plascencia, A.; Zinn, R.A. 2006. Influence of exogenous fibrolytic enzyme supplementation and maceration process in a low-quality forage on digestion parameters and rumen function in dry Holstein cows. Veterinaria México 37: 275-289.

Lu, C.D.; Jorgensen, N.A.; Barrington, B.P. 1980. Intake, digestibility, and rate of passage of silages and hay from wet fractionation of alfalfa. Journal of Dairy Science 63: 2051-2059. 
Moore, J,A.; Poore, M.H.; Swingle, R.S. 1990. Influence of roughage source on kinetics of digestion and passage, and on calculated extents of ruminal digestion in beef steers fed $65 \%$ concentrate diets. Journal of Animal Science 68:3412-3420.

National Research Council [NRC]. 1996. Nutrient Requirements of Beef Cattle. 7ed. National Academy of Press, Washington D.C., USA.

Petit, H.V.; Savoie, P.; Tremblay, D.; Dos Santos, G.T.; Buttler, G. 1994. Intake, digestibility, and ruminal degradability of shredded hay. Journal of Dairy Science 77:3043-3050.

Petit, H.V.; Tremblay, G.F.; Savoie, P. 1997. Performance of growing lambs fed two levels of concentrate with conventional or macerated timothy hay. Journal of Animal Science 75:598-603.

Plascencia A.; Lopez-Soto, A.M.; Montaño, M.F.; Serrano, J.; Ware, R.A.; Zinn, R.A. 2007. Influence of surfactant supplementation and maceration on the feeding value of rice straw in growing-finishing diets for Holstein steers. Journal of Animal Science 85:2575-2581.

Plascencia, A.; Zinn, R.A. 2002. Evaluation of a forage: fat blend as an isocaloric substitute for steam-flaked wheat in finishing diets for feedlot cattle: Growth-performance and digestive function. The Professional Animal Scientist. 18:247-253.

Rohweder, D. A.; Barnes, R.F.; Jorgensen, N.A. 1978. Proposed hay grading standards based on laboratory analyses for evaluating quality. Journal of Animal Science 47:747-759.
SAS Institute. 2009. SAS/STAT ${ }^{\mathbb{B}} 9.2$ User's Guide. 2ed. SAS Institute, Cary, NC, USA.

Shinners, K. J.; Koegel, R.G.; Straub, R.J. 1988. Design considerations and performance of forage maceration devices. Applied Engineering in Agriculture 4:13-18.

Ware, R.A.; Torrentera, N.G.; Zinn, R.A. 2005. Influence of maceration and fibrolytic enzymes on the feeding value of rice straw. Journal of Animal and Veterinary Advances 4: 387-392.

Zinn, R.A. 1990. Influence of flake density on the comparative feeding value of steam-flaked corn for feedlot cattle. Journal of Animal Science 68: 767-775.

Zinn, R.A.; Owens, F.N. 1986. A rapid procedure for purine measurement and its use for estimating net ruminal synthesis. Canadian Journal of Animal Science 66:157-164.

Zinn, R.A.; Plascencia, A. 1993. Interaction of whole cottonseed and supplemental fat on digestive function in cattle. Journal of Animal Science 71:11-17.

Received October 15, 2010

Accepted May 24, 2011 